Terbit online pada laman web jurnal : http://teknosi.fti.unand.ac.id/

\title{
PENGUJIAN KINERJA SERVER PORTABLE BERBASIS SINGLE BOARD COMPUTER (SBC) DALAM MENDUKUNG KEGIATAN PEMBELAJARAN
}

\author{
Lathifah Ariefa, Fajril Akbar ${ }^{b}$, Nefy Puteri Novani ${ }^{a}$, Iqbal Saputra ${ }^{a}$ \\ a Prodi Sistem Komputer, Fakultas Teknologi Informasi, Universitas Andalas, Padang, 25163, Indonesia \\ ${ }^{b}$ Prodi Sistem Informasi, Fakultas Teknologi Informasi, Universitas Andalas, Padang, 25163, Indonesia
}

\begin{tabular}{|c|}
\hline INFORMASI ARTIKEL \\
\hline $\begin{array}{l}\text { Sejarah Artikel: } \\
\text { Diterima Redaksi: } 15 \text { November } 2017 \\
\text { Revisi Akhir: } 30 \text { Agustus } 2018 \\
\text { Diterbitkan Online: } 02 \text { September } 2018\end{array}$ \\
\hline KATA KUNCI \\
\hline $\begin{array}{l}\text { Portable, } \\
\text { SBC Server, } \\
\text { Wi-Fi Direct, } \\
\text { Performance Testing, } \\
\text { NMON }\end{array}$ \\
\hline KORESPONDENSI \\
\hline
\end{tabular}

Telepon: +62 81322574766

E-mail: lathifah.arief@.fti.unand.ac.id

\section{A B S T R A C T}

\begin{abstract}
Dukungan fasilitas komputer atau alat bantu kegiatan hands-on lainnya jelas dibutuhkan dalam membekali keterampilan praktis bidang komputasi dan teknologi informasi kepada peserta didik. Dalam penelitian ini, diusulkan suatu portable server berbasis single board computer (SBC) dan teknologi WiFi-direct untuk menjadi alat bantu pembelajaran dengan beberapa karakteristik: (a) portable secara fisik, (b) rendah biaya, (c) dapat diakses dari berbagai platform perangkat pengguna, dan (d) tidak mengandalkan ketersediaan koneksi internet. Fokus penelitian ini adalah rancang bangun portable server tersebut dan pengujian kinerjanya ketika digunakan dalam pembelajaran hands-on. Server yang dibangun berhasil diakses oleh beberapa perangkat berbeda (dicobakan hingga 4 platform perangkat yang berbeda) baik secara terpisah maupun secara bersamaan. Pengujian kinerja yang dilakukan mencakup pengujian waktu respon sistem dan pengujian penggunaan sumber daya komputasi server. Pengujian waktu respon sistem dilakukan untuk mengetahui berapa lama waktu yang dibutuhkan dan harus dialokasikan untuk persiapan server dalam kerangka waktu kegiatan pembelajaran. Hasil yang didapatkan cukup baik, yaitu total waktu terlama sejak server booting sampai pengguna berhasil login adalah 2 menit 45 detik. Pengujian penggunaan sumber daya komputasi server pada paper kali ini difokuskan berupa baselining untuk mendapatkan gambaran penggunaan sumber daya server dalam kondisi beban minimum ketika hanya diakses oleh pengguna tunggal yang hanya mengakses satu tool pembelajaran saja. Baseline penggunaan sumberdaya komputasi server yang didapatkan meliputi penggunaan sumber daya CPU, memory dan network untuk beberapa skenario: akses melalui kabel UTP, akses melalui hotspot server, aktivitas remote shell, aktivitas remote desktop, dan akses suatu tool pembelajaran berbasis command line interface (CLI). Tindak lanjut yang diharapkan dari penelitian ini adalah pengujian waktu respon, pengujian beban, serta pengujian batas kemampuan server ketika diakses secara simultan oleh banyak pengguna yang mewakili lazimnya jumlah peserta suatu kelas.
\end{abstract}

\section{PENDAHULUAN}

Hampir setiap perguruan tinggi di Indonesia saat ini memiliki program studi yang berfokus di bidang teknologi informasi (TI), yang lulusannya ditargetkan memiliki keterampilan praktis yang sesuai dengan kebutuhan industri. Kebanyakan perguruan tinggi masih kesulitan mencapai target ini karena untuk membekali mahasiswa dengan keterampilan praktis diperlukan kombinasi antara kompetensi pengajar yang baik, pembelajaran yang berpusat pada siswa, serta fasilitas media pembelajaran yang memadai. Kalaupun pembekalan keterampilan praktis ini dapat diberikan melalui praktikum, sumber daya laboratorium umumnya masih terbatas jumlahnya dan hanya dapat diakses selama sesi praktikum. Jika diharapkan pembekalan ini juga dapat disisipkan dalam kegiatan pembelajaran di kelas, pembelajaran https://doi.org/10.25077/ TEKNOSI.v4i2.2018.098-106 seringkali dilaksanakan di ruang kuliah bersama yang tak jarang mengalami perubahan lokasi, yang masing-masingnya belum tentu memiliki fasilitas media pengajaran yang seragam. Oleh karena itu, dibutuhkan suatu alat bantu pembelajaran semacam portable labs berbiaya rendah yang mampu untuk mengatasi kendala-kendala ini [1].

Pada penelitian sebelumnya, telah dirancang suatu alat bantu pembelajaran yang bersifat portable yang dapat digunakan untuk menawarkan kurikulum intensif suatu laboratorium online [2]. Disamping itu, ada pula penelitian yang berfokus pada pengembangan modul pembelajaran keamanan, khususnya pada aspek keamanan, analisis ancaman dan perlindungan perangkat mobile, yang modul tersebut diakses melalui perangkat mobile pula [3][4]. Pendekatan yang agak berbeda dalam pengembangan alat bantu pembelajaran yang portable juga dilakukan dalam 
penelitian terpisah yang memanfaatkan single board computer (SBC) BeagleBone Black untuk pembelajaran embedded system design [5] dan yang menggunakan Xen untuk pembelajaran keamanan komputer dalam lingkungan virtual [6].

Dari beberapa penelitian di atas diketahui bahwa alat bantu pembelajaran berbasis SBC juga memiliki keterbatasan, di antaranya spesifikasi sumber daya komputasinya belum memadai untuk komputasi kompleks maupun untuk banyak akses secara simultan. Selain itu, alat bantu pembelajaran pada penelitianpenelitian tersebut umumnya masih membutuhkan ketersediaan koneksi jaringan, sehingga memiliki ketergantungan pada satu jaringan tertentu, dan juga hanya dapat diakses melalui perangkat tertentu saja, contohnya dari perangkat mobile.

Dalam penelitian ini, diusulkan suatu portable server berbasis single board computer (SBC) sebagai alat bantu pembelajaran dengan karakteristik: (a) portable secara fisik yaitu dapat mudah dibawa berpindah tempat, (b) relatif rendah biaya, (c) dapat diakses dari berbagai platform perangkat pengguna, dan (d) tidak mengandalkan ketersediaan koneksi internet. Portable server tersebut dirancang untuk dapat menyediakan media pembelajaran dan memfasilitasi kegiatan hands-on secara fleksibel karena tools atau software yang akan digunakan dapat diakses melalui halaman web atau aplikasi SSH.

Fokus penelitian ini adalah rancang bangun portable server tersebut dan pengujian atas kinerjanya ketika digunakan dalam kegiatan belajar mengajar di kelas maupun di lab. Pada penelitian ini, portable server yang dikembangkan diujikan penggunaannya pada dua mata kuliah berbeda, yaitu mata kuliah Keamanan Informasi dan mata kuliah Pemrograman Multi Platform, yang sama-sama memiliki target capaian hard skill bersifat hands-on.

Oleh karena itu, dapat dirumuskan bahwa permasalahan yang menjadi fokus penelitian ini antara lain bagaimana membangun server pembelajaran yang bersifat portable dan rendah biaya, serta bagaimana memantau serta menguji kinerjanya saat sedang digunakan untuk kegiatan pembelajaran.

\section{TINJAUAN PUSTAKA}

\subsection{Single Board Computer (SBC)}

Single board computer adalah komputer yang dibangun di atas papan sirkuit utama yang biasanya mencakup sebuah mikroprosesor (atau dapat pula banyak), RAM, dan unit I/O. Ini semua adalah persyaratan minimal untuk memiliki komputer yang berfungsi penuh. Single board komputer dapat digunakan untuk banyak hal, mulai dari untuk keperluan pendidikan atau demo, pengembangan purwarupa produk, pengendali komputer tertanam (embedded) atau sebagai perangkat media streaming. Ada banyak produk single board computer yang telah berkembang atau beredar di pasaran dan telah digunakan untuk berbagai tujuan tersebut. Di antaranya berasal dari keluarga Beagleboard, Odroid, pcDuino, Orange Pi, Banana Pi, Raspberry $P i$, maupun ratusan keluarga SBC lainnya.
Raspberry Pi, salah satunya, merupakan komputer mungil seukuran dengan sebuah kartu kredit dengan berbagai fungsi yang dapat dilakukannya. Selain ukurannya yang jauh lebih kecil dari komputer biasa, kemampuan komputer mini ini pun di bawah komputer biasa. Raspberry Pi kebanyakan digunakan untuk kegiatan pembelajaran yang tidak memerlukan alokasi memori yang besar seperti belajar pemrograman. Dalam jajak pendapat tahunan yang diadakan oleh LinuxGizmos.com, di mana di tahun 2017 dilakukan terhadap 1.705 responden, Raspberry Pi 3 model B terpilih sebagai SBC pilihan nomor 1 dari 97 SBC lainnya. Di antara alasan unggulnya Raspberry Pi 3 model B dalam jajak pendapat tersebut adalah faktor harganya yang relatif murah (price per performance), juga faktor ketersediaan dokumentasi dan dukungan komunitasnya yang paling banyak dan aktif [7]. Dengan alasan inilah, maka dalam penelitian ini SBC yang digunakan sebagai server pembelajaran adalah Raspberry Pi 3 model B.

\subsection{Wi-Fi Direct}

Untuk memastikan aspek portabilitas fisik dan kemerdekaan dari kebergantungan pada jaringan tertentu, dalam penelitian ini dipilih komunikasi data antara perangkat pengguna dengan server pembelajaran berupa teknologi Wi-Fi Direct. Wi-Fi Direct adalah teknologi yang didefinisikan oleh Wi-Fi Alliance dengan tujuan agar perangkat-perangkat dapat terhubung secara langsung, Device to Device (D2D), atau peer-to-peer (P2P), dengan cepat untuk melakukan perintah-perintah seperti pengiriman data, sinkronisasi, dan lain lain. Wi-Fi direct tidak memerlukan penggunaan jalur akses terpusat, berbeda halnya dengan Wi-Fi tradisional. Sebaliknya, perangkat menggunakan "Access Point" [8].

Komunikasi antar perangkat pada Wi-Fi Direct terjadi dalam satu grup dimana di dalam group tersebut ada yang bertindak sebagai P2P Group Owner (GO). Setelah P2P GO terpilih, maka peran masing-masing klien tidak akan berubah selama sesi seluruh group. Ketika P2P GO meninggalkan grup, maka klien akan terputus dan melakukan proses pencarian perangkat lagi untuk membentuk grup baru.

Grup pada Wi-Fi direct bekerja mirip halnya dengan infrastruktur BSS WLAN yang beroperasi pada saluran tunggal di mana setiap klien pada group dapat berkomunikasi. P2P GO juga bertugas untuk mengiklankan grupnya secara berkala sehingga memungkinkan perangkat lain untuk menemukan dan bergabung pada grup tersebut. Dengan kata lain, pada Wi-Fi Direct, P2P GO merupakan perangkat yang menerapkan fungsi Access Point (AP) di dalam grup.

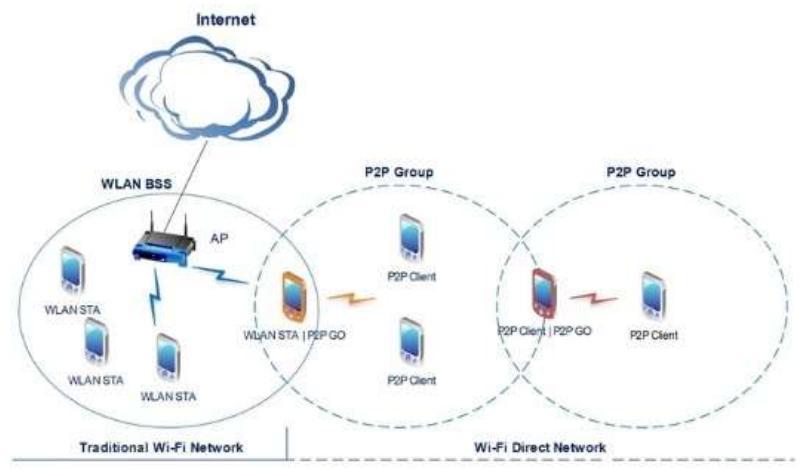

Gambar 1. Arsitektur Jaringan Wi-Fi Direct [9]

Lathifah Arief 
Pada Gambar 1 di atas, terlihat keberadaan P2P GO pada suatu $P 2 P$ Group bertindak sebagai pihak yang bertanggung jawab atas grup, termasuk mengendalikan perangkat yang diizinkan untuk bergabung selama sesi grup tersebut. P2P GO juga membuat suatu Access Point (AP) yang memungkinkan perangkat lain untuk terhubung pada P2P GO meskipun tidak memiliki dukungan teknologi Wi-Fi Direct. Perangkat tersebut dapat dikatakan sebagai Legacy Client (LC).

LC merupakan perangkat Wi-Fi konvensional yang tidak memiliki dukungan Wi-Fi Direct dan akan "melihat" P2P GO tadi seperti layaknya Wi-Fi Access Point (AP) tradisional. Secara umum, LC tidak termasuk dalam group Wi-Fi Direct dan tidak dapat ditingkatkan fungsionalitasnya. LC hanya sekedar dapat melihat P2P GO sebagai AP tradisional biasa. Dalam konektivitas yang terbentuk antara P2P Client (ataupun LC) kepada P2P GO, P2P GO akan menyediakan suatu DHCP lease dan IP Address layaknya Access Point biasa.

\subsection{Sumber Daya Komputasi}

Sumber daya komputasi merupakan sumber daya yang dimiliki oleh suatu komputer, yang kinerjanya mempengaruhi kinerja komputer tersebut. Sumber daya komputasi yang umumnya dipantau dari suatu komputer yang diuji, berikut dengan parameter pemantauan atau pengujiannya antara lain:

- Processor: processor usage, interrupt, context switches, dan seterusnya.

- Memory: jumlah memori fisik dan virtual yang tersedia, penggunaan memori cache, tingkat baca halaman, dst.

- Network: paket diterima/dikirim dan total byte yang ditransfer melalui jaringan dan setiap adapter jaringan per detik, aktivitas protokol, dan seterusnya.

\subsection{Aplikasi Pemantau}

Aplikasi pemantau merupakan aplikasi yang digunakan untuk memantau kinerja dari sumber daya komputasi seperti cpu, memori, jaringan, disk, dan lain-lain. Setelah dilakukan pemantauan, maka akan tentukan tindakan untuk mengatasi permasalahan yang terjadi dalam sumber daya komputasi. Contoh aplikasi pemantau ini antara lain seperti Cacti, MRTG, TCPDump dan yang digunakan dalam penelitian ini yaitu Nigel's performance Monitor (NMON).

NMON merupakan salah satu tool untuk melakukan sistem administrasi, tuning, dan benchmarking yang memberikan informasi penting kondisi sumber daya sistem. Informasi tersebut di antaranya kondisi CPU, memori, jaringan, disk, dan lain-lain. Data hasil pemantauan disimpan dalam file berekstensi .nmon, dan dapat dilihat secara grafis dengan bantuan NMONchart.

\section{METODOLOGI}

Metode yang digunakan pada penelitian ini adalah metode penelitian secara percobaan (experimental research). Dalam melaksanakan penelitan ini, terdapat tujuh tahapan yang terdiri dari (1) identifikasi masalah, (2) studi literatur dan kepustakaan, (3) analisis kebutuhan fungsionalitas, perangkat keras dan perangkat lunak sistem, (4) perancangan sistem, (5) implementasi sistem, (6) pengujian dan analisis hasil, lalu ditutup dengan (7) dokumentasi hasil. Oleh karena fokus penelitian ini juga ditekankan pada pengujian kinerja sistem, maka tahap pengujian mendapat porsi pembahasan yang lebih banyak dalam paper ini.

Pengujian kinerja sistem dikelompokkan menjadi dua jenis pengujian, yaitu (a) pengujian kinerja dari segi waktu respon sistem, dan (b) pengujian kinerja dari segi penggunaan sumber daya komputasi server.

Pengujian waktu respon sistem dilakukan untuk mengetahui berapa lama waktu yang dibutuhkan dan harus dialokasikan untuk persiapan server dalam kerangka waktu kegiatan pembelajaran. Terdapat lima tahap skenario pengujian waktu respon server:

1. Pengujian durasi waktu booting server

2. Pengujian durasi waktu munculnya SSID hotspot server di perangkat pengguna

3. Pengujian durasi waktu koneksi perangkat pengguna ke hotspot server (dari satu hingga empat koneksi simultan)

4. Pengujian durasi waktu login pengguna dari perangkat pengguna ke server

Pada pengujian jenis yang kedua, pengujian penggunaan sumber daya komputasi server, pada paper kali ini difokuskan pada baselining, yaitu pengujian yang bertujuan untuk mendapatkan baseline penggunaan sumber daya server dalam kondisi beban server berupa beban minimum karena hanya berasal dari koneksi pengguna tunggal.

Di tahap ini diterapkan lima skenario variasi cara penggunaan portable server tersebut oleh pengguna yang mungkin terjadi dalam kegiatan pembelajaran. Di setiap skenario, terdapat bagian yang dijaga tetap dan terdapat pula bagian yang diubah dari skenario sebelumnya agar dapat dilihat efek perubahan tersebut terhadap kinerja sumber daya komputasi server.

Lima skenario yang diterapkan mewakili variasi cara penggunaan portable server tersebut yang mungkin terjadi dalam kegiatan pembelajaran yaitu:

a. Skenario 1: mengakses ke server dalam mode terminal (command line interface, CLI) melalui kabel UTP;

b. Skenario 2: melakukan remote access ke server dalam mode terminal/CLI melalui Wi-Fi Direct Access Point (hotspot) server;

c. Skenario 3: melakukan remote access ke server dalam mode grafis (graphical user interface, GUI) melalui hotspot server;

d. Skenario 4: melakukan remote access ke server melalui hotspot server, kemudian menjalankan salah satu tool pembelajaraan yang berbasis CLI, dalam kasus ini Nmap.

e. Skenario 5: melakukan remote access ke server melalui hotspot server, kemudian menjalankan salah satu tool pembelajaran yang berbasis web. Namun hasil pegujian ini dibahas dalam publikasi terpisah yang berfokus pada load testing dan stress testing server pembelajaran dengan modul pembelajaran berbasis web.

Setiap skenario pengujian dilakukan sebanyak 3 kali pengujian masing-masingnya selama 30 detik.

https://doi.org/10.25077/ TEKNOSI.v4i2.2018.098-106 
Penggunaan sumber daya komputasi server yang dipantau pada setiap skenario adalah penggunaan CPU, memory dan network server pembelajaran. Pada penggunaan CPU, yang dipantau ada empat item pantauan, yaitu:

a. CPU idle, yaitu persentase waktu CPU saat tidak memproses perintah apapun dan sistem tidak memiliki permintaan I/O disk yang belum terselesaikan.

b. CPU I/O wait, yaitu persentase waktu CPU saat tidak memproses perintah apapun, namun pada saat sistem memiliki permintaan I/O disk yang belum terselesaikan.

c. CPU system-level usage, yaitu persentase penggunaan CPU sementara mengeksekusi pada sistem atau kernel.

d. CPU user-level usage, yaitu persentase penggunaan CPU sementara mengeksekusi perintah pengguna.

Pada penggunaan memory, ada lima item pantauan:

a. Memory Free merupakan alokasi memori yang bebas dan dapat dipakai.

b. Cached merupakan daerah memori yang dialokasikan untuk menyimpan sementara data aplikasi agar lebih cepat diakses nantinya.

c. Active merupakan alokasi memori yang digunakan.

d. Buffer merupakan daerah memori yang dialokasikan untuk menyangga kerja antar perangkat keras maupun antar aplikasi atau program yang memiliki kecepatan atau memiliki prioritas eksekusi perintah yang berbeda.

e. Inactive merupakan memori yang dialokasikan untuk proses yang tidak berjalan lagi.

Pada penggunaan network, ada dua item pantauan:

a. Network receive, merupakan paket yang diterima oleh server untuk permintaan remote.

b. Network send, merupakan paket yang dikirimkan oleh server ke perangkat klien.

\section{HASIL DAN PEMBAHASAN}

\subsection{Spesifikasi Kebutuhan Sistem}

Kebutuhan fungsional yang harus disediakan oleh sistem yang dikembangkan dalam penelitian ini antara lain:
- Sistem dapat menyediakan suatu komunikasi wireless secara langsung antara perangkat pengguna dengan server tanpa bergantung pada ketersediaan akses internet,

- Sistem mampu menampilkan materi pembelajaran yang dapat diakses oleh lebih dari 1 pengguna secara simultan,

- Sistem dapat menampilkan serta menyimpan data kegiatan pembelajaran secara unik per pengguna,

- Sistem dapat mengetahui kondisi sumber daya komputasi server ketika server sedang diakses,

- Sistem dapat menyimpan data hasil pemantauan kondisi sumber daya komputasi secara unik per waktu snapshot.

Kebutuhan non-fungsional sistem antara lain:

- Sistem dapat menyediakan koneksi antara perangkat pengguna dalam masa tenggang persiapan kuliah, yaitu sekitar 5 menit pertama perkuliahan;

- Sistem dapat menampilkan hasil pemantauan kinerja dengan tampilan grafis yang mudah dimengerti pengajar.

Perangkat keras yang dibutuhkan untuk membentuk sistem antara lain:

- $\quad$ SBC Raspberry Pi 3 model B

- Power adapter dengan spesifikasi 5V 2,4 A

- MicroSD berukuran 16 GB untuk memuat sistem operasi

Perangkat lunak yang dibutuhkan dalam mengembangkan sistem antara lain:

- Sistem operasi berbasis Linux (Kali Linux dan Raspbian)

- LAMP (Linux, Apache, MySQL, PHP) Server

- Perangkat NMON, NMONChart, dan NMONAnalyzer

- VNCServer dan VNCViewer untuk akses GUI

- Mobile SSH/Termius/PuTTY untuk akses CLI

\subsection{Rancangan Umum Sistem}

Gambar 2 adalah gambaran umum rancangan sistem yang dikembangkan dalam penelitian ini.

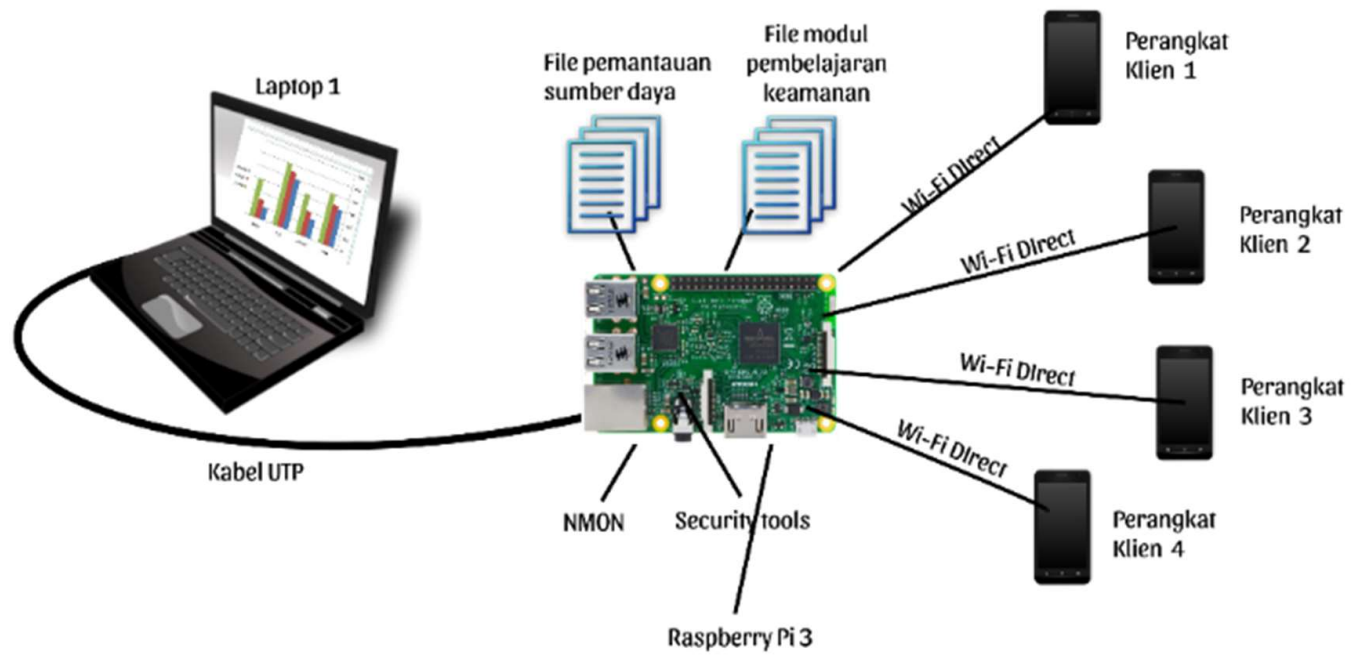

Gambar 2. Rancangan Umum Sistem

Gambar 3 menunjukkan konfigurasi Wi-Fi Direct yang

digunakan. 


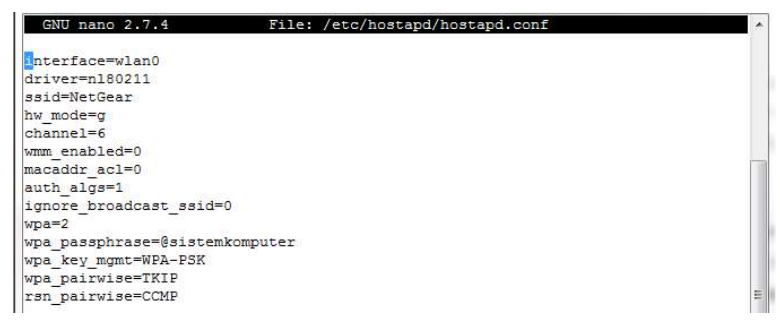

Gambar 3. Konfigurasi Wi-Fi Direct

Untuk menghubungkan perangkat klien ke server digunakan teknologi Wi-Fi direct. Teknologi ini memberikan peran hotspot pada server untuk memungkinkan hubungan langsung antara perangkat pengguna dengan server. Teknologi ini memiliki seluruh keunggulan Wi-Fi, mulai dari jangkauan, transfer data, dan kapasitas pengiriman data.

\subsection{Pengujian Kinerja Sistem}

\subsubsection{Pengujian Waktu Respon Sistem}

1. Durasi Waktu Booting Server sampai Login

Booting merupakan proses hidupnya perangkat sampai perangkat siap dipakai oleh pengguna. Terdapat dua jenis booting, yaitu cold booting dan warm booting. Cold booting yaitu proses menghidupkan perangkat dari keadaan mati, sedangkan warm booting adalah proses menghidupkan kembali perangkat yang sebelumnya telah hidup.

Pengujian waktu booting pada skenario ini menggunakan cold booting. Hal ini dikarenakan cold booting lebih sering dilakukan server di awal kegiatan pembelajaran. Warm booting kemungkinan hanya dilakukan ketika server melakukan pembaharuan atau jika terjadi kesalahan pada server yang mengharuskan server itu mengalami warm booting.

Berdasarkan data yang diperoleh, waktu booting server tidak mengalami perbedaan antara kelima data pemantauan, yaitu sama-sama sebesar 2 menit 26 detik. Waktu booting tersebut tergolong singkat mengingat keterbatasan spesifikasi perangkat keras pada server. Sebagai perbandingan, ketika pengujian yang sama dilakukan kepada Raspberry Pi 2 model B, waktu cold booting yang didapatkan mendekati 5 menit.

\section{Durasi Waktu Munculnya SSID Hotspot Server}

Pengujian dilakukan dengan memantau daftar list Wi-Fi yang ada diperangkat klien dari mulai sejak server melakukan awal booting sampai muncul SSID hotspot server di perangkat pengguna. Pengujian ini bertujuan untuk melihat kemampuan server membentuk fungsi Access Point dengan dukungan teknologi $\mathrm{Wi}$ Fi Direct.

Berdasarkan data yang didapat, waktu munculnya SSID dari hotspot server hamper bersamaan dengan waktu booting server, yaitu 2 menit 26 detik. Ini menandakan bahwa hotspot pada server sudah otomatis berjalan sehingga dapat mempromosikan SSIDnya segera setelah booting selesai.

\section{Durasi Waktu Koneksi Perangkat Pengguna ke Server}

Pengujiannya dilakukan dengan memantau waktu saat perangkat pengguna melakukan sambungan ke hotspot server dari perangkatnya hingga status hubungan antara keduanya adalah

Lathifah Arief terkoneksi (connected). Pengujian ini bertujuan untuk mengukur kemampuan server dalam merespon permintaan akses $\mathrm{Wi}-\mathrm{Fi}$ direct dari klien. Pengujian awalnya dilakukan secara terpisah dari empat perangkat yang berbeda, dan kemudian dilakukan secara simultan keempat perangkat.

Tabel 1 Durasi Waktu Koneksi Empat Perangkat Ke Server

\begin{tabular}{|c|c|c|c|c|}
\hline \multicolumn{5}{|c|}{ Percobaan Durasi Waktu Koneksi } \\
\hline Ke & $\begin{array}{c}\text { Perangkat } \\
1\end{array}$ & $\begin{array}{c}\text { Perangkat } \\
2\end{array}$ & $\begin{array}{c}\text { Perangkat } \\
\mathbf{3}\end{array}$ & $\begin{array}{c}\text { Perangkat } \\
4\end{array}$ \\
\hline 1 & 8 detik & 8 detik & 9 detik & 8 detik \\
\hline 2 & 9 detik & 6 detik & 7 detik & 6 detik \\
\hline 3 & 7 detik & 4 detik & 7 detik & 4 detik \\
\hline 4 & 7 detik & 5 detik & 6 detik & 4 detik \\
\hline 5 & 6 detik & 4 detik & 5 detik & 5 detik \\
\hline Rata-rata & $\begin{array}{c}7,4 \\
\text { detik }\end{array}$ & $\begin{array}{c}5,4 \\
\text { detik }\end{array}$ & $\begin{array}{c}6,8 \\
\text { detik }\end{array}$ & $\begin{array}{c}5,4 \\
\text { detik }\end{array}$ \\
\hline $\begin{array}{c}\text { Rata-rata } \\
\text { keseluruhan }\end{array}$ & & & etik & \\
\hline
\end{tabular}

Dari pengujian terpisah masing-masing perangkat klien, didapati bahwa waktu yang dibutuhkan untuk menghubungkan perangkat klien ke hotspot server bervariasi, dengan waktu terlama untuk terciptanya koneksi adalah 11 detik. Banyak faktor yang menyebabkan berbedanya waktu yang dibutuhkan untuk menghubungkan perangkat klien ke hotspot server, diantaranya:

1. Jarak antara perangkat klien dengan server

2. Kualitas jaringan hotspot server

3. Kesiapan perangkat server

4. Kesiapan perangkat klien

Pada pengujian secara simultan, durasi waktu koneksi keempat perangkat klien diperlihat pada tabel 1 .

Pengujian ini bertujuan untuk melihat kemampuan server dalam merespon permintaan $\mathrm{Wi}$-Fi direct secara simultan. Pengujian dilakukan dengan memantau waktu dari empat perangkat klien melakukan sambungan ke hotspot server secara bersamaan. Berdasarkan hasil pengujian, server tidak mengalami permasalahan ketika menerima permintaan koneksi Wi-Fi direct secara simultan. Semua perangkat klien terhubung ke hotspot server dengan selisih waktu 0.6 sampai 2 detik saja. Bahkan ada perangkat yang memiliki waktu terhubung yang sama dengan perangkat yang lain. Secara keseluruhan, rata-rata durasi waktu koneksi keempat perangkat juga termasuk baik yaitu 6,25 detik dengan waktu terlama adalah 9 detik.

\section{Durasi Waktu Login Pengguna ke Server}

Pengujian ini bertujuan untuk mengetahui rata-rata durasi waktu yang dibutuhkan untuk pengguna melakukan login ke server pembelajaran. Terdapat dua acara akses untuk mengakses server, yaitu berbasis terminal alias CLI dan berbasis desktop alias GUI. Pada pengujian ini, pengaksesan server secara remote dilakukan dengan basis terminal yang menggunakan aplikasi mobile SSH.

Pengujian dilakukan dengan perangkat klien yang digunakan berupa smartphone Android. Dari hasil pengujian didapatkan bahwa waktu yang dibutuhkan untuk login dari lima kali pengujian adalah sama yaitu 10 detik. Kesamaan ini dapat dicapai asalkan dalam percobaan tidak ada yang membuat proses login bermasalah.

https://doi.org/10.25077/ TEKNOSI.v4i2.2018.098-106 
Secara keseluruhan, hasil pengujian kinerja sistem dari aspek waktu respon sistem memberikan hasil yang baik, dengan nilai total dari rata-rata seluruh proses mencapai 2 menit 42,25 detik dan hasil terlama adalah 2 menit 45 detik. Hasil ini masih dapat dianggap baik dalam kerangka waktu persiapan pembelajaran.

\subsubsection{Pengujian Penggunaan Sumber Daya Komputasi Server}

Hasil dari pengujian tahap pertama, yaitu baselining kinerja server dengan berbagai variasi skenario penggunaan server dalam kegiatan pembelajaran disampaikan sebagai berikut.

\section{Skenario 1: Koneksi ke Server Melalui Kabel}

Pada skenario 1, terdapat satu laptop yang bertindak sebagai stasiun pemantau kinerja server untuk mewakili klien, dan terdapat kabel UTP sebagai penghubung antara laptop dan server secara lokal. Akses ke server dilakukan dengan mode terminal/CLI. Akses dilakukan dengan protokol SSH (port 22) dengan menggunakan aplikasi PuTTY. Pemantauan kinerja dilakukan setelah akses berhasil dilakukan. Data pemantauan di skenario ini digunakan untuk mendapatkan baseline ketika di server dijalankan aplikasi pemantau kinerja server yang akan diakses melalui komunikasi kabel dari laptop staf pengajar.

Tabel 2 Penggunaan CPU (\%) pada Skenario 1

\begin{tabular}{ccccc}
\hline \multicolumn{5}{c}{ Pemantauan } \\
\hline Ke & Idle & Wait & System & User \\
\hline $\mathbf{1}$ & $93.1 \%$ & $1.3 \%$ & $4.3 \%$ & $1.3 \%$ \\
\hline $\mathbf{2}$ & $90.4 \%$ & $0 \%$ & $5.1 \%$ & $4.5 \%$ \\
\hline $\mathbf{3}$ & $94.7 \%$ & $0 \%$ & $4.5 \%$ & $2.8 \%$ \\
\hline $\begin{array}{c}\text { Rata- } \\
\text { rata }\end{array}$ & $\mathbf{9 2 . 7 \%}$ & $\mathbf{0 . 4 \%}$ & $\mathbf{4 \%}$ & $\mathbf{2 . 9 \%}$ \\
\hline
\end{tabular}

Secara keseluruhan, rata-rata penggunaan CPU oleh sistem hanya $4 \%$ dengan penggunaan tertinggi hanya mencapai $5,1 \%$. Adapun rata-rata penggunaan oleh pengguna hanya sebesar $2,9 \%$ dengan penggunaan tertinggi hanya mencapai $4,5 \%$.

Tabel 3 berikut menunjukkan rata-rata penggunaan memory pada Skenario 1.

Tabel 3 Penggunaan Memori (MB) pada Skenario 1

\begin{tabular}{|c|c|c|c|c|c|c|}
\hline \multicolumn{7}{|c|}{ Pemantauan } \\
\hline $\mathrm{Ke}$ & $\begin{array}{c}\text { Memory } \\
\text { Total }\end{array}$ & $\begin{array}{l}\text { Memory } \\
\text { Free }\end{array}$ & Cached & Active & $\begin{array}{c}\text { Buffe } \\
\text { rs }\end{array}$ & $\begin{array}{c}\text { Inactiv } \\
\mathbf{e}\end{array}$ \\
\hline 1 & 925.9 & 736.3 & 99.7 & 83.7 & 84.7 & 78 \\
\hline 2 & 925.9 & 654.4 & 159 & $\begin{array}{c}150 . \\
2\end{array}$ & 27.6 & 88.2 \\
\hline 3 & 925.9 & 654.2 & 129 & 150 & 27.6 & 88.1 \\
\hline $\begin{array}{l}\text { Rata- } \\
\text { rata }\end{array}$ & 925.9 & 681.6 & 129.2 & 128 & 46.6 & 84.8 \\
\hline
\end{tabular}

Dari hasil yang didapatkan nampak bahwa penggunaan memori tidak terlalu besar, ditunjukkan dengan memory free rata-rata masih mencapai 681.6 MB. Hal ini dapat dimengerti mengingat tidak ada proses lain yang dijalankan selain remote access ke shell.

Tabel 4 berikut menunjukkan rata-rata penggunaan network pada Skenario 1.

Tabel 4 Penggunaan Network eth0 (KBps) pada Skenario 1

\begin{tabular}{ccc}
\hline Pemantauan & Receive (Read) & Send (Write) \\
\hline $\mathbf{1}$ & $6.8 \mathrm{KBps}$ & $403.9 \mathrm{KBps}$ \\
\hline $\mathbf{2}$ & $1 \mathrm{KBps}$ & $78 \mathrm{KBps}$ \\
\hline $\mathbf{3}$ & $1 \mathrm{KBps}$ & $62.2 \mathrm{KBps}$ \\
\hline Rata-rata & $\mathbf{2 . 9} \mathrm{KBps}$ & $\mathbf{1 8 1 . 4} \mathrm{KBps}$ \\
\hline
\end{tabular}

Berdasarkan hasil percobaan, diperoleh rata-rata untuk receive/read pada ethernet (eth0) adalah $2,9 \mathrm{KBps}$ dengan nilai tertinggi sebesar $6,8 \mathrm{KBps}$ dan terendah $1 \mathrm{KBps}$. Adapun nilai rata-rata untuk send/write untuk ethernet (eth0) tersebut adalah 181,4 KBps dengan nilai tertinggi sebesar 403,9 KBps dan terendah $62,2 \mathrm{KBps}$.

Masih rendahnya penggunaan sumberdaya komputasi server di skenario ini dapat dimengerti mengingat tidak ada proses lain yang dijalankan selain remote access ke shell.

2. Skenario 2: Koneksi CLI ke Server melalui HotSpot Server Pada skenario kedua ini, laptop dihubungkan ke server melalui hotspot server. Akses remote ke server dilakukan dengan protokol SSH (port 22) dengan aplikasi PuTTY. Pemantauan sumber daya dilakukan setelah akses remote berhasil dilakukan.

Hasil pemantauan di skenario ini nantinya akan dibandingkan dengan hasil pemantauan ketika skenario yang sama dilakukan secara simultan oleh 30 pengguna dari perangkat masing-masing pada paper terpisah.

Tabel 5 Penggunaan CPU (\%) pada Skenario 2

\begin{tabular}{ccccc}
\hline Pemantauan & Idle & Wait & System & User \\
\hline $\mathbf{1}$ & $93.9 \%$ & $0 \%$ & $5.1 \%$ & $1 \%$ \\
\hline $\mathbf{2}$ & $94.7 \%$ & $0 \%$ & $4 \%$ & $1.4 \%$ \\
\hline $\mathbf{3}$ & $94.5 \%$ & $0 \%$ & $4.2 \%$ & $1.4 \%$ \\
\hline Rata-rata & $\mathbf{9 4 . 4 \%}$ & $\mathbf{0 \%}$ & $\mathbf{4 . 4 \%}$ & $\mathbf{1 . 2 \%}$ \\
\hline
\end{tabular}

Dibandingkan skenario 1, penggunaan CPU oleh sistem pada skenario kedua ini nampak lebih meningkat, sedangkan oleh pengguna nampak mengalami penurunan. Hal serupa ditunjukkan oleh hasil pemantauan penggunaan memori.

Tabel 6 Penggunaan Memori (MB) pada Skenario 2

\begin{tabular}{ccccccc}
\hline \multicolumn{7}{c}{ Pemantauan } \\
\hline $\mathrm{Ke}$ & $\begin{array}{c}\text { Memory } \\
\text { Total }\end{array}$ & $\begin{array}{c}\text { Memory } \\
\text { Free }\end{array}$ & Cached & Active & Buffers & Inactive \\
\hline 1 & 925.9 & 675.5 & 143.7 & $\begin{array}{c}140 . \\
7\end{array}$ & 32.7 & 77.4 \\
\hline 2 & 925.9 & 675.5 & 143.7 & $\begin{array}{c}140 . \\
7\end{array}$ & 32.7 & 77.4 \\
\hline 3 & 925.9 & 610.7 & 156.7 & $\begin{array}{c}155 . \\
8\end{array}$ & 32.9 & 89.7 \\
\hline $\begin{array}{c}\text { Rata } \\
\text {-rata }\end{array}$ & $\mathbf{9 2 5 . 9}$ & $\mathbf{6 5 3 . 9}$ & $\mathbf{1 4 8 . 0}$ & $\mathbf{1 4 5 .}$ & $\mathbf{3 2 . 8}$ & $\mathbf{8 1 . 5}$ \\
\hline
\end{tabular}

Rata-rata penggunaan memori aktif pada skenario kedua adalah 145,7 MB, meningkat dibandingkan skenario pertama. Hal ini diperkirakan akibat penggunaan $\mathrm{Wi}$-Fi direct sehingga proses komunikasi grup akan bertambah dan menempati memori.

Tabel 7 Penggunaan Network wlan0 (KBps) pada Skenario 2

\begin{tabular}{ccc}
\hline Pemantauan & Receive (Read) & Send (Write) \\
\hline 1 & $0.3 \mathrm{KBps}$ & $0.1 \mathrm{KBps}$ \\
\hline 2 & $0.1 \mathrm{KBps}$ & $0.1 \mathrm{KBps}$ \\
\hline 3 & $0,1 \mathrm{KBps}$ & $0,1 \mathrm{KBps}$ \\
\hline Rata-rata & $\mathbf{0 , 2} \mathrm{KBps}$ & $\mathbf{0 , 1} \mathbf{K B p s}$ \\
\hline
\end{tabular}


Karena pada skenario 2 ini perangkat klien terhubung ke server melalui hotspot server, maka pemantauan difokuskan pada aktivitas network wlan0, berbeda dengan pemantauan pada skenario 1 yang difokuskan pada aktivitas network eth0.

Rata-rata penggunaan network wlan0 adalah $0,2 \mathrm{KBps}$ (receive) dan $0,1 \mathrm{KBps}$ (send), lebih rendah daripada network eth0 sebelumnya.

3. Skenario 3: Koneksi GUI ke Server melalui Hotspot Server

Pada skenario ini, laptop dihubungkan ke server melalui hotspotnya, dan kemudian dilakukan akses GUI (remote desktop) dengan menggunakan aplikasi VNCViewer.

Tabel 8 Penggunaan CPU (\%) pada Skenario 3

\begin{tabular}{ccccc}
\hline Pemantauan & Idle & Wait & System & User \\
\hline 1 & $86.2 \%$ & $0 \%$ & $2.9 \%$ & $10.9 \%$ \\
\hline 2 & $91.2 \%$ & $0 \%$ & $5.1 \%$ & $3.7 \%$ \\
\hline 3 & $89.6 \%$ & $0 \%$ & $5.9 \%$ & $4.5 \%$ \\
\hline Rata-rata & $\mathbf{8 9 \%}$ & $\mathbf{0 \%}$ & $\mathbf{4 . 6 \%}$ & $\mathbf{6 . 3 \%}$ \\
\hline
\end{tabular}

Dibandingkan skenario 2, terdapat peningkatan baik pada pemakaian CPU oleh sistem maupun oleh pengguna. Hal ini diperkirakan karena pada skenario ini di server harus berjalan VNCServer untuk menampilkan tampilan desktop ke pengguna.

Tabel 9 Penggunaan Memori (MB) pada Skenario 3

\begin{tabular}{ccccccc}
\hline \multicolumn{7}{c}{ Pemantauan } \\
\hline Ke & $\begin{array}{c}\text { Memory } \\
\text { Total }\end{array}$ & $\begin{array}{c}\text { Memory } \\
\text { Free }\end{array}$ & Cached & Active & Buffers & Inactive \\
\hline 1 & 925.9 & 610.7 & 156.7 & 188.8 & 32.9 & 89.7 \\
\hline 2 & 925.9 & 609.6 & 156.8 & 189.4 & 32.9 & 89.7 \\
\hline 3 & 925.9 & 610 & 159.6 & 140.7 & 32.9 & 89.8 \\
\hline $\begin{array}{c}\text { Rata- } \\
\text { rata }\end{array}$ & $\mathbf{9 2 5 . 9}$ & $\mathbf{6 1 0 . 1}$ & $\mathbf{1 5 7 . 7}$ & $\mathbf{1 7 3 . 0}$ & $\mathbf{3 2 . 9}$ & $\mathbf{8 1 . 7}$ \\
\hline
\end{tabular}

Hasil pemantauan penggunaan memori pada skenario ini juga menunjukkan peningkatan. Hal ini karena server harus menjalankan VNCServer yang membutuhkan alokasi memori. Peningkatan bukan hanya terjadi pada memori active namun juga terjadi pada cached dan buffer. Nilai cached meningkat $6,6 \%$ dibandingkan dengan skenario 2 karena aplikasi VNCServer mengisi cache di memori untuk meningkatkan kinerja aplikasi.

Hasil pemantauan penggunaan sumberdaya network pada skenario ini diperlihatkan sebagai berikut.

Tabel 10 Penggunaan Network wlan0 (KBps) pada Skenario 3

\begin{tabular}{ccc}
\hline Pemantauan & Receive (Read) & Send (Write) \\
\hline 1 & $11.8 \mathrm{KBps}$ & $791.8 \mathrm{KBps}$ \\
\hline 2 & $0.3 \mathrm{KBps}$ & $16.7 \mathrm{KBps}$ \\
\hline 3 & $11.8 \mathrm{KBps}$ & $19 \mathrm{KBps}$ \\
\hline Rata-rata & $\mathbf{8 . 0 ~ K B p s}$ & $\mathbf{2 7 5 . 8} \mathbf{K B p s}$ \\
\hline
\end{tabular}

Dibandingkan dengan skenario 2, meski sama-sama mengakses server melalui $\mathrm{Wi}$-Fi direct, terjadi peningkatan yang signifikan dalam arus komunikasi data akibat penggunaan aplikasi VNCServer. Aplikasi ini diperkirakan membutuhkan sumber daya jaringan yang juga besar untuk secara realtime memperbaharui perubahan tampilan desktop ke viewer pengguna.

4. Skenario 4: Koneksi ke Server melalui Hotspot Server untuk Menjalankan Tool Berbasis CLI

Lathifah Arief
Pada skenario ini, empat perangkat pengguna dengan platform yang berbeda (laptop dan smartphone, dengan sistem operasi Linux, Windows dan Android) dihubungkan ke server melalui hotspot-nya yang kemudian melakukan login ke server. Laptop menggunakan aplikasi PuTTY sedangkan smartphone menggunakan aplikasi mobile SSH untuk login. Setelah itu, dari akses jarak jauh tersebut, dijalankan tool Nmap untuk memindai suatu target.

Tabel 11 Penggunaan CPU (\%) pada Skenario 4

\begin{tabular}{ccccc}
\hline Pemantauan & Idle & Wait & System & User \\
\hline 1 & $93.3 \%$ & $1.1 \%$ & $3.5 \%$ & $2 \%$ \\
\hline 2 & $94.3 \%$ & $0 \%$ & $3.6 \%$ & $2.2 \%$ \\
\hline 3 & $94.7 \%$ & $0 \%$ & $4.7 \%$ & $0.6 \%$ \\
\hline Rata-rata & $\mathbf{9 4 . 1 \%}$ & $\mathbf{1 . 1 \%}$ & $\mathbf{3 . 9 \%}$ & $\mathbf{1 . 6 \%}$ \\
\hline
\end{tabular}

Dibandingkan dengan skenario 3 yang sama-sama mengakses server melalui Wi-Fi Direct, tampak penggunaan CPU oleh sistem di sini mengalami penurunan. Hal ini karena di skenario 3 ada VNCServer yang lebih banyak mengkonsumsi sumber daya server dibandingkan tool NMap berbasis CLI di skenario 4 .

Namun, dibandingkan dengan skenario 2 yang sama-sama menggunakan WiFi-Direct dan CLI, penggunaan CPU pengguna atau aplikasi di skenario 4 ini mengalami peningkatan. Hal tersebut karena pada skenario 2 pengguna hanya menjalan perintah dasar di shell, sedangkan di skenario 4 ada penggunaan sumber daya CPU oleh tool Nmap yang dijalankan pengguna.

Tabel 12 Penggunaan Memori (MB) pada Skenario 4

\begin{tabular}{ccccccc}
\hline \multicolumn{7}{c}{ Pemantauan } \\
\hline Ke & $\begin{array}{c}\text { Memory } \\
\text { Total }\end{array}$ & $\begin{array}{c}\text { Memory } \\
\text { Free }\end{array}$ & Cached & Active & Buffers & Inactive \\
\hline 1 & 925.9 & 654 & 95.2 & 86 & 115 & 158 \\
\hline 2 & 925.9 & 654.2 & 95.2 & 189.4 & 115.5 & 155.9 \\
\hline 3 & 925.9 & 609.2 & 129 & 129 & 115.5 & 156.2 \\
\hline $\begin{array}{c}\text { Rata } \\
\text {-rata }\end{array}$ & $\mathbf{9 2 5 . 9}$ & $\mathbf{6 3 9 . 1}$ & $\mathbf{1 0 6 . 5}$ & $\mathbf{1 3 4 . 8}$ & $\mathbf{1 1 5 . 3}$ & $\mathbf{1 5 6 . 7}$ \\
\hline
\end{tabular}

Dibandingkan dengan skenario 2, terjadi peningkatan yang signifikan jumlah penggunaan buffers dan memori inactive, sebaliknya penurunan memori active dan cached.

Penurunan pada memori active dan cached diperkirakan terjadi karena selama tool Nmap melakukan pemindaian pada jaringan, tidak ada aktivitas lainnya dari pengguna atau tools lainnya. Sedangkan penggunaan buffer pada memori meningkat signifikan karena kedua perangkat yang terhubung ke server sama-sama menyimpan data sementara hasil pemindaian untuk disampaikan kemudian laporannya di akhir pengerjaan oleh tool. Peningkatan memori inactive diperkirakan karena VNCServer yang sebelumnya dijalankan, di skenario ini tidak lagi digunaan.

Tabel 13 Penggunaan Network wlan0 (KBps) pada Skenario 4

\begin{tabular}{ccc}
\hline Pemantauan & Receive (Read) & Send (Write) \\
\hline 1 & 0.3 & 0.4 \\
\hline 2 & 0.3 & 0.3 \\
\hline 3 & 0.3 & 0 \\
\hline Rata-rata & $\mathbf{0 . 3}$ & $\mathbf{0 . 2}$ \\
\hline
\end{tabular}

Hasil pemantauan sumber daya jaringan menunjukkan bahwa terjadi penurunan drastis dibandingkan skenario 3, dan hanya mengalami peningkatan yang tipis dibandingkan skenario 2 . Hal ini dikarenakan, di skenario ini tidak ada lagi kebutuhan pembaharuan tampilan desktop secara realtime seperti akses GUI

https://doi.org/10.25077/ TEKNOSI.v4i2.2018.098-106 
di skenario 3. Tipisnya peningkatan yang dialami jika dibandingkan dengan skenario 2 adalah karena selain untuk menjalankan tool Nmap, perangkat pengguna hanya terhubung ke server tanpa aktivitas apapun, sehingga tidak ada lalu lintas jaringan yang berarti.

\subsection{Perbandingan Hasil Pemantauan}

A. Skenario 1 dengan Skenario 2

Tujuan perbandingan ini adalah untuk mengetahui perbandingan kinerja sumber daya CPU, memori dan network server ketika suatu perangkat pengguna terhubung ke server menggunakan kabel UTP dan ketika menggunakan hotspot server. Pada kedua skenario ini, pengguna sama-sama hanya mengakses server namun belum melakukan proses lain apapun.

Hasil perbandingan yang didapatkan dari tabel rata-rata penggunaan CPU server kedua skenario ini adalah:

a. CPU idle mengalami peningkatan (pada skenario 2) sebesar $1,7 \%$.

b. $\mathrm{CPU} \mathrm{I} / \mathrm{O}-$ wait mengalami penurunan sebesar $0,4 \%$.

c. CPU system-level usage mengalami peningkatan $0,4 \%$.

d. CPU user-level usage mengalami penurunan $1,7 \%$.

Hasil perbandingan penggunaan memori adalah:

a. Memori active mengalami peningkatan sebesar $17.7 \mathrm{MB}$

b. Memori free mengalami penurunan sebesar $27 \mathrm{MB}$

Hasil perbandingan penggunaan network adalah:

a. Receive mengalami penurunan sebesar $27 \mathrm{KBps}$

b. Send mengalami penurunan sebesar $180 \mathrm{KBps}$

B. Skenario 2 dengan Skenario 3

Tujuannya perbandingan ini adalah untuk mengetahui perbandingan kinerja sumber daya CPU, memori dan network server ketika perangkat pengguna terhubung ke server untuk mengakses CLI ( $\mathrm{SSH}$ ) dengan mengakses GUI (remote desktop). Pada kedua skenario ini, perangkat pengguna sama-sama terhubung ke server melalui akses WiFi-direct ke hotspot server.

Hasil perbandingan yang didapatkan dari tabel rata-rata penggunaan CPU server kedua skenario ini adalah:

a. CPU idle mengalami peningkatan sebesar $5,4 \%$.

b. CPU I/O wait dalam keadaan konstan.

c. CPU system-level usage mengalami peningkatan $0,2 \%$

d. CPU user-level usage mengalami peningkatan 5,1\%

Hasil perbandingan penggunaan memori adalah:

a. Cached mengalami peningkatan $9,7 \mathrm{MB}$

b. Buffer mengalami peningkatan $0,1 \mathrm{MB}$.

Hasil perbandingan penggunaan sumber daya network:

a. Received mengalami peningkatan 8 kali dari skenario 2

b. Send mengalami peningkatan 2700 kali dari skenario 2

C. Skenario 2 dan Skenario 4

Tujuan perbandingan ini adalah untuk mengetahui perbandingan kinerja sumber daya CPU, memori dan network server ketika terdapat dua perangkat pengguna yang berbeda, terhubung dengan cara yang sama dengan skenario 2 namun menjalan tool pembelajaran berbasis CLI (di sini berupa Nmap).

Hasil perbandingan yang didapatkan dari tabel rata-rata penggunaan CPU server kedua skenario ini adalah:

a. CPU idle mengalami peningkatan sebesar $0,3 \%$. b. CPU I/O wait mengalami peningkatan sebesar $1,1 \%$.

c. CPU system-level usage mengalami penurunan $0,5 \%$.

d. CPU user-level usage mengalami peningkatan $0,4 \%$.

Hasil perbandingan yang didapatkan dari tabel rata-rata penggunaan memori server kedua skenario ini adalah :

a. Buffer mengalami peningkatan yang signifikan sebesar 3,5 kali dari pada skenario 2 .

b. Inactive mengalami peningkatan dikarenakan pernah ada aplikasi yang dijalankan.

\section{KESIMPULAN}

Berdasarkan perancangan dan implementasi server portable berbasis single board computer (SBC) yang telah dilakukan, dan berdasarkan pengujian kinerja yang telah dilakukan terhadap server tersebut, dapat diambil kesimpulan sebagai berikut:

1. Server portable tersebut dapat diakses melalui beberapa perangkat berbeda (dicobakan hingga 4 platform perangkat yang berbeda) secara bersamaan dengan hasil pemantauan sebagai berikut :

a. Waktu booting rata-rata adalah 2 menit 26 detik.

b. Nama SSID hotspot yang disediakan server dengan teknologi $\mathrm{Wi}$-Fi direct juga berhasil langsung muncul pada perangkat klien sekitar 2 menit 26 detik sejak awal server booting.

c. Hotspot berfungsi dengan baik dengan waktu koneksi terlama dari perangkat ke server adalah 11 detik, rata-rata 6,25 detik.

d. Hotspot dapat diakses secara simultan oleh lebih dari satu perangkat pengguna dengan platform yang berbeda, namun terbuka kemungkinan untuk mengalami perbedaan waktu respon.

2. Hasil pemantauan penggunaan sumber daya komputasi berhasil memberikan baseline penggunaan sumberdaya CPU, memori dan network untuk kasus akses melalui kabel UTP, akses melalui hotspot server, aktivitas dengan remote CLI, aktivitas dengan remote GUI, dan kasus menjalankan tool pembelajaran berbasis remote CLI.

3. Hasil pengujian kinerja server melalui load testing dan stress testing akses simultan terhadap modul pembelajaran berbasis web disampaikan dalam paper terpisah, yang data pengujiannya masih bersumber dari hasil pemantauan pada penelitian yang sama.

4. Sebagai lanjutan dari penelitian ini, saat ini sedang dikembangkan server berbasis SBC-cluster untuk pengembangan purwarupa pembelajaran mesin (machine learning), yang akan dipaparkan dalam paper terpisah.

\section{UCAPAN TERIMA KASIH}

Penelitian ini didanai oleh skim penelitian dosen pemula FTIUNAND dengan nomor kontrak: 10/UN16.15/PL/FTI-2017.

\section{DAFTAR PUSTAKA}

[1] Lo, Dan Chia-Tien, Kai Qian, and Wei Chen. "Mobile security education on portable labs." In Frontiers in Education Conference (FIE), 2015 IEEE, pp. 1-4. IEEE, 2015.

[2] Lo, Dan Chia-Tien, Kai Qian, Wei Chen, and Tamara Rogers. "A Low Cost, Portable Platform for Information Assurance and Security Education." In Advanced Learning Technologies (ICALT), 2015 IEEE 
15th International Conference on, pp. 111-113. IEEE, 2015.

[3] Guo, Minzhe, Prabir Bhattacharya, Ming Yang, Kai Qian, and Li Yang. "Work in progress: Real world relevant security labware for mobile threat analysis and protection experience." In Frontiers in Education Conference (FIE), 2012, pp. 1-2. IEEE, 2012.

[4] Mahmoud, Qusay H. "Integrating mobile devices into the computer science curriculum." In Frontiers in Education Conference, 2008. FIE 2008. 38th Annual, pp. S3E-17. IEEE, 2008.

[5] He, Nannan, Ying Qian, and Han-way Huang. "Experience of teaching embedded systems design with BeagleBone Black board." In Electro Information Technology (EIT), 2016 IEEE International Conference on, pp. 0217-0220. IEEE, 2016.

[6] $\mathrm{Hu}$, Dong, and YuYan Wang. "Teaching computer security using xen in a virtual environment." In Information Security and Assurance, 2008. ISA 2008. International Conference on, pp. 389-392. IEEE, 2008.

[7] LinuxGizmos.com. "2017 Hacker Board Survey: Raspberry Pi Still Rules but x86 SBCs Make Gains". http://linuxgizmos.com/2017-hacker-board-surveyraspberry-pi-still-rules-but-x86-sbcs-make-gains/ [July, 21, 2017]

[8] Camps-Mur, Daniel, Andres Garcia-Saavedra, and Pablo Serrano. "Device-to-device communications with Wi-Fi Direct: overview and experimentation." IEEE wireless communications 20, no. 3 (2013): 96104.

[9] Khan, Muhammad Asif \& Chérif, Wael \& Filali, Fethi \& Ridha, Hamila. (2017). "Wi-Fi Direct Research Current Status and Future Perspectives." Journal of Network and Computer Applications. 93. 10.1016/j.jnca.2017.06.004

[10] Smartbear. "Load Testing: Measuring Server Hardware Performance".

https://support.smartbear.com/viewarticle/78998/\#Perf ormanceMetrics, [June, 19, 2017]

\section{BIODATA PENULIS}

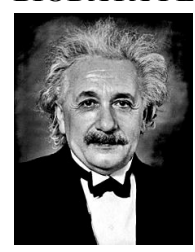

\section{Lathifah Arief}

Penulis adalah dosen pada prodi Sistem Komputer FTI UNAND, mengajar mata kuliah Keamanan Informasi dan memiliki pengalaman pemanfaatan single board computer untuk projek terkait keamanan dan pemrograman.

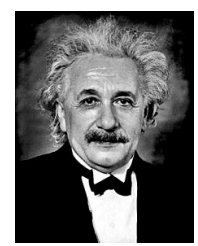

Fajril Akbar

Penulis adalah dosen pada prodi Sistem Informasi FTI UNAND, memiliki pengalaman di berbagai projek pembangunan sistem otomasi yang menggunakan single board controller dan single board computer.

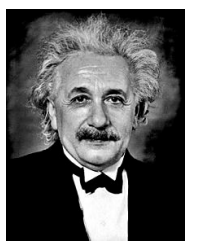

Nefy Puteri Novani

Penulis adalah dosen pada prodi Sistem Komputer FTI UNAND, mengajar mata kuliah Pemrograman Multi Platform dan Organisasi Arsitektur Komputer, memiliki ketertarikan pada variasi penerapan single board computer.

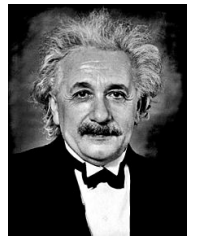

Iqbal Saputra

Penulis menyelesaikan studinya dari prodi Sistem Komputer FTI UNAND dengan tugas akhir berfokus pada monitoring penggunaan sumber daya single board computer yang difungsikan sebagai web server lokal. 